\title{
Exploring the Contemporary Visual Usages of Chinese Character Aesthetics: A Perspective from Aesthetic Economy
}

\author{
Bowan Zhang \\ Master Student, National Cheng Kung University, Institute of Creative Industries Design, Taiwan
}

\begin{abstract}
As the oldest character that is still in use today, Chinese character has been giving off aesthetic value besides its usable function all through China's long history. Bird-and-Insect Script in Spring and Autumn Period was an initiation to reckon characters as artworks. In Tang Dynasty, "the Diamond Sutra" included three design elements that are text, title and illustration, becoming the earliest role model of graphic design. In a contemporary view, China's development attracted unprecedented attention; the Internet age changed the way how people appreciate art. Therefore, the research on Chinese character aesthetics at present has time significance than ever before.

To provide theoretical support, a three-dimensional matrix is built during the process of literature review for Chinese character aesthetics. Taking the space dimension as horizontal axis and the time dimension as vertical axis. Aesthetic economy is treated as the third axis to discover the potential development of Chinese character aesthetics in a deeper way.

This research chose one case from each of the three highly visual-related industries including art, design and cultural creative industries. Following, field study, questionnaire, archival research and interview will be applied to obtain data depend on features of the cases. At last, cross-case analysis and content analysis based on the data will help to generate conclusions and suggestions.
\end{abstract}

Keywords: Chinese Character Aesthetics, Chinese Character Art, Chinese Character Design, Aesthetic Economy, Visual Image, Sinosphere

\section{Introduction}

\subsection{Research Background}

Chinese character is considered as the earliest pictograph that still exists today; it is also recognized as one of the most complicated characters all over the world. Chinese character records life and behaviour of our ancestors and makes China become one of the earliest cradles of civilization. In other words, the long history of Chinese character enables the shared-value between the ancients who lived thousands years ago and the modern people.

Another key thing to remember is that Chinese character has the largest number of users nowadays. Besides China, it also spreads over several countries in Asia, such as Japan, Korea and Singapore. Plenty of places in Western Countries use Chinese character as well. Nowadays, with China's rapid economical growth and the improvement of the international competitiveness, more and more foreigners are willing to learn Chinese. However, most of them just treat Chinese as a communication tool without any awareness of Chinese character Aesthetics.

The Internet era goes along with the advanced technology. Therefore, the way people use Chinese character is changing from handwritten to computer-assisted. During the updating process of computers and mobile phones' technologies, people's aesthetic value orientation has changed dramatically as well. As a result, aesthetic ideology and aesthetic measurement are being restructured in the transformation period. Thus it can be 
seen that it is meaningful to examine and explore Chinese character aesthetics from the contemporary perspective.

\subsection{Research Motivation}

I learned Chinese calligraphy from my grandfather since I was 4 years old. I have been fully interested in handwriting and generated keen curiosity of Chinese character. At each stage of my life, it provides me with variable inspirations of creation and makes me think about philosophical questions, and even shares life experience with me.

Besides, Contemporary visual art and design also attract me significantly. Further more, travelling broadly has been enlarging my understanding towards contemporary visual art and design.

\subsection{Research Objectives and Questions}

In consideration of the research background and research motivation above, the researcher comes up with four research objectives as below,

- To investigate different opinions on the relationship between functionality and aesthetics of Chinese characters

- To identify the conceptual evolution of Chinese character aesthetics

- To integrate the current development of Chinese character aesthetics in contemporary visual art, design and cultural creative industries (CCI)

- To reposition Chinese character aesthetics in perspective of aesthetic economy

Research questions carry out according to research objectives in sequence, details are as below,

- How to measure the arguments between functionality and aesthetic value of Chinese character?

- What is the evolution process of the concept of Chinese Character Aesthetics?

- To what extent has Chinese character Aesthetics in contemporary visual art, design and CCI?

How to reposition Chinese character aesthetics in perspective of aesthetic economy?

\section{Literature Review}

\subsection{Rethinking the Contemporary Values of Chinese Character}

Any characters including Chinese character provide two distinct types of experience to their users that are aesthetic sensibility and function.

Some scholars think that character function is more important than the aesthetic facet. Beatrice Warde expressed her viewpoints in the article named "the crystal goblet or printing should be visible", saying that the principal usage of characters is to convey the ideas from one mind to other minds. The fonts are similar to the transparent crystal wineglass, containing the content without covering. But people still can appreciate the delicate quality and beautiful design of the glass (Warde 1955). Chiang (2009) holds similar opinions that the basic usage of characters is to deliver and communicate ideas. Practicability goes ahead, following the aesthetic sensibilities. Zhu touched this topic when he was interviewed (Liao, 2009), stating that the characters must be used at the first place, and then the extent of beauty can be taken account of.

However, others insist that Chinese character aesthetics should be paid more attention to. The transformation of human artistic activities from practicability-driven to impracticability-driven is a sign that means human beings' spiritual progress. It represented that the historical evolution from merely surviving to live to pursuing higher spiritual aesthetic activities (Kong et al, 2002). The functional value of characters is practical while the aesthetic value of characters is impractical. As the improvement of technology and the fulfilment of material life, the target of artistic activities has been changing. Japanese Sinologist Shirakawa(1978) regarded Chinese character as the carrier of beauty. Chinese character makes the pretty pattern and the beautiful minds come true.

Another standpoints consider that there is no conflict between function and aesthetics. Aesthetic sensibilities

are part of function, pleasing the users and implementing the usages more efficiently(Ke et al, 2014). Beauty 
interacts with the legibility of Chinese characters ( $\mathrm{Li}, 2006)$. In another way, some people reckon function as one type of beauty that is named functional beauty. Socrates, the ancient Greek philosophers, expressed his opinion that anything that can achieve its target in function aspect is good and beautiful.

We can divide the contemporary value of Chinese character in several ways. From another perspective, any characters contain three dimensions, which are shape, rhythm and meaning. This research will focus on the aesthetic and shape aspect to examine the visual value of Chinese character.

The system of Chinese character is a combination of pictures, signs and symbols. Because of the gap between them, they are hard to unify in a reasonable order. Visual image is a concept generally covering pictures, signs and symbols (Zang, 1995). Visual image reveals the universal connections. It can bypass the domains that related to actual things and also give places to the domains that particularly reappear things ( $\mathrm{Li}, 2015)$. With the upgrades of Chinese character types, the distance between the character and its described objects becomes farer and farer; however, it is getting closer to the abstract symbolic sign. As a result, the expression of emotions and meanings can be achieved by the symbolic meaning. Visual image means that Chinese character can be treated as an abstract element and makes it possible to be applied broadly in a wider range such as contemporary art, design and CCI.

The aesthetic sensibility towards Chinese types and calligraphy is cultivated unconsciously on those users who take Chinese character as communication tools. In 1985, Ma convened the China modern calligraphy and painting Academy, modern calligraphy suddenly appeared on the horizon since then. During the late 90s, modern artists $\mathrm{Wu}, \mathrm{Gu}$ and $\mathrm{Xu}$ started to rethink Chinese character through counterfeit, recreation and restructure. In 2002, Pu published the new concept of Chinese character art. The generation of this concept is because that calligraphy cannot cover the boundaries where Chinese character art works had achieved any longer. In 2003, Pu established the first Chinese character art website. In 2005, Chinese character art faculty was newly introduced in Peking University, which was the first design major particularly focusing on Chinese character in China (Fu, 2011). It can be seen that Chinese character art has been given birth for over 30 years. During the 3 decades, it kept changing people's attitude about how to appreciate the art world.

In a broad sense, the relationship between Chinese character and design is reflected in two ways. On one hand, it can be analyzed from the perspective of thinking model. Visual images of Chinese character influence design styles superficially. However, the inner logics and the resultant design thinking methods consist of the core elements of Chinese design style. On the other hand, Chinese character is considered as an unique element of design ( $\mathrm{Li}, 2006)$. From the narrow sense, Chinese character design represents what we called lettering, which takes characters as design objects. For design industry, Chinese character visual application is undoubtedly the starting point as well as the ultimate inspiration origin, contributing new energy to the design industry in both the Western and the Eastern.

Hsu and Lin(2011) examined the methodology of the Chinese character's application on CCI. They divided the creative process of Chinese character into three steps. The first step is to extract the cultural features from Chinese character through analysis, changing original materials into useful elements. The second step is to develop feasible application and generate practical conceptual model. Then the third step is to form intellectual property and achieve the industrial transformation. Besides, Chinese character elements are frequently applied on cultural creative products.

\subsection{A Closer Look into Chinese Character Aesthetics}

The spirit of Chinese character aesthetics originated from the masterpiece named "The literary mind and the carving dragon" written by the Southern Dynasty literary theorist Liu Xie in the year 500 A.D. Liu Xie pointed out the aesthetic measurement of Chinese character shape is harmony and symmetry (Liang, 2007). In the year of 1750, the concept of aesthetics was given birth in German. Since then, Chinese litterateurs, calligraphers and artistic theorists have been devoting themselves to exploring and discovering the relationships between Chinese character art and aesthetics. During the past 100 years, with the increasing communication between the Eastern 
and the Western world, more and more Chinese scholars who have western educational background have been making further explanation of the aesthetic features of Chinese character from the perspective of cross-culture. Lin Yutang wrote "My Country and My People" in 1935, stating that calligraphy provided a set of academic terms to aesthetic appreciation. Zong Baihua pointed out his views in 1960s that the aesthetic law was abstracted from Greek temples for western aesthetics and became the forms of beauty in western aesthetics. In consequence, we can conclude the scope of Chinese aesthetics from how ancient Chinese people judged and measured calligraphy. And the conclusion can be compared to western aesthetics to check the similarities and differences in order to enrich the aesthetic contents of the whole world (Yao, 1996).

After 2000, aesthetic value of Chinese character was paid unprecedented attention to. The theoretical boundary of Chinese character expanded remarkably and is not limited to calligraphy any longer. With the rapid progress of Computer and Internet technology, Chinese characters that are input and displayed on computers and mobile phones became a major part. Besides, pictorial Chinese character, hand-made Chinese character with various materials such as flowers or foods are all included in the research scope of Chinese character aesthetics. The unique aesthetic value of Chinese character comes from its original pictographic nature as well as the harmony and equilibrium of the structure (Qin, 2001).

At present, Chinese character users mainly live in Mainland China, Hong Kong, Macau and Taiwan Districts. In Japan, the "Commonly Used Chinese Characters Table" recorded 2229 Chinese characters in all. Chinese is still the official written language in Korea nowadays. In addition, Chinese is also broadly used in Singapore, Malysia and Tailand. The area where used or is currently using Chinese is named Sinosphere (Li, 2001). Synergic effect in Sinosphere serves from three dimensions. Firstly, language dimension means that anyone who uses Chinese can understand other forms of Chinese without effort. Secondly, cultural dimension means that we are all immersed in the traditional society formation under Confucianism. Thirdly, mind dimension makes it possible for all the people live in Sinosphere to share same feeling in the universe. No matter in China, Japan, Korea or Singapore, when people appreciate the moon light in the sky in mid-autumn day, they all follow the poetries of Li Bai and fall in thoughts. Synergic effect is the key spiritual element to reunify the whole Sinosphere (Vandermeersch, 汪德邁 et al. 1993).

\subsection{Aesthetic Economy: the Trends of Chinese Character Aesthetics}

Aesthetic economics research on the value of products and service created by aesthetic sensibilities. In another manner of speaking, the business activities to combine aesthetic life experience and industrial development are aesthetic economics. For example, in Taiwan, Professor Li proposed to develop a new business mode based on aesthetic lifestyle in order to make more profits. In Mainland China, the subject is called economic aesthetics. Professor Fan thinks that it is a new subject mutually crossed by two existed subjects, stating the general law of beauty's initiation and development in production and consumption domains (Shi, 2009).The sources of aesthetic sensibilities are broader than those of art, and they are easier to be accepted by the public. As a result, to discover the breakthrough of Chinese character aesthetics industrialization, the theoretical basis of aesthetic economics can be borrowed.

\section{Research Methods}

Since this research tries to explore a new topic from new perspective. In order to avoid limitation of one single case, one case will be selected from three industries including art, design and CCI, therefore three cases in all. The cross-case analysis provides a contemporary visual usages' vertical comparison between different industries with a wide coverage. To investigate single case, the research will use content analysis method. In considerations of research cost, research effectiveness and approach complexity, the research selects research methods of literature review, questionnaire, archival research, field study and interview. For each case, more than one method will be used depending on the availabilities when performing. 
This research selects cases following the principles of rationality, originality and researchability. Firstly, rationality is the basis to measure feasibilities of selected cases. They should be consistent with common sense and knowledge. Secondly, the selected cases should be new, meaning they happened recently or they are seldom researched before. The distance between the selected research cases and the existed research is helpful to enrich the academic world. Thirdly, the cases should be able to research on. The primary data and secondary data should be sufficient.

TABLE I: Basic Information of the Research Cases

\begin{tabular}{|c|c|c|c|}
\hline NO. & $\begin{array}{l}\text { Category 1: Chinese } \\
\text { character visual art }\end{array}$ & $\begin{array}{c}\text { Category 2: Chinese character } \\
\text { design }\end{array}$ & $\begin{array}{l}\text { Category 2: Chinese } \\
\text { character applied to } \mathrm{CCI}\end{array}$ \\
\hline Name & Xue Song(薛松) & 653 Calligraphy & Chen Nan (陳楠) \\
\hline Occupation & Professional painter & Calligraphy design studio & $\begin{array}{l}\text { Professor in Academy of Fine } \\
\text { Arts }\end{array}$ \\
\hline Main Works & $\begin{array}{l}\text { Beijing; Secret Signs - } \\
\text { Calligraphy in Chinese } \\
\text { Contemporary Art, } \\
\text { Deichtorhallen Art Museum, } \\
\text { Hamburg }\end{array}$ & $\begin{array}{l}\text { It organizes calligraphy } \\
\text { workshops from design } \\
\text { perspective in order to change } \\
\text { people's stereotype of Chinese } \\
\text { calligraphy }\end{array}$ & $\begin{array}{l}\text { Oracle bone inscription } \\
\text { stickers; Creative Chinese } \\
\text { type ceramics products }\end{array}$ \\
\hline Location & Shanghai & Tainan & Beijing \\
\hline $\begin{array}{l}\text { Research } \\
\text { Methods }\end{array}$ & $\begin{array}{l}\text { Archival research; Field } \\
\text { Study; Interview, } \\
\text { Questionnaire }\end{array}$ & $\begin{array}{l}\text { Archival research; Field Study; } \\
\text { Interview, Questionnaire }\end{array}$ & $\begin{array}{l}\text { Archival research; Field } \\
\text { Study; Interview, } \\
\text { Questionnaire }\end{array}$ \\
\hline $\begin{array}{l}\text { Field Study } \\
\text { Plan }\end{array}$ & $\begin{array}{l}\text { Tainan Art Exhibition 2018, } \\
\text { Loftyard Gallery }\end{array}$ & $\begin{array}{l}\text { Exhibition in Elite Bookstore in } \\
\text { Tainan in January } 2018 .\end{array}$ & $\begin{array}{l}\text { Creative products online shop } \\
\text { “格物館” on Taobao and } \\
\text { Wechat-shop. }\end{array}$ \\
\hline
\end{tabular}

\section{Data Analysis and Conclusion}

The researcher collected both primary and secondary data. For the primary data, field study, questionnaire and interview methods can be used. During the process of field study, non-participant observation helps to get the information of environment, activities and conditions. During the process of interview, we may collect answers from interviewees that are not limited to the guidance to interpret their perceptions and feelings. Questionnaire is an efficient and effective way to get consumer's viewpoints. On the other hand, secondary data is obtained through archival research. Any recorded data can be viewed as research data for this method. The sources include the traditional newspaper, magazines and letters, and the new media such as Internet press, official accounts articles on Wechat, publications of art galleries and even personal Weibo.

The data analysis methods of this research are mainly consisted of two types, which are content analysis and cross-case analysis. Content analysis is applied to single cases, while cross-case analysis is used to explore the similarities and differences of multiple cases.

Based on the collected data and analysis, the researcher obtains three conclusions as follows.

First, art galleries, museums, select shops and other creative consumption places are playing an agency role between designers/artists and consumers. The agencies manipulate and beautify the creators inevitably when promoting them to the art market. Therefore, misunderstanding exists due to improper information delivery.

Second, normal art consumers' awareness towards Chinese character aesthetics are still in a relatively low situation. Although they consider Chinese character as beautiful elements of art or design works, however, they are more likely to ignore the cultural connection behind the superficial visual experience.

Third, normal art consumers are tired of traditional creative products just like postcards or stickers. They are willing to see more cross-industry cooperation between Chinese character aesthetics and fine art (not limited to calligraphy). New categories can increase their consumption possibilities. 


\section{Acknowledgements}

My deepest gratitude goes first and foremost to Professor Chung, my supervisor, for her constant encouragement and guidance. She has walked me through all the stages of the writing of this thesis. Without her consistent and illuminating instruction, this thesis could not have reached its present form.

Second, I would like to express my heartfelt gratitude to my beloved family for their loving considerations and great confidence in me all through these years. I also owe my sincere gratitude to my friends and my fellow classmates who gave me their help and time in listening to me and helping me work out my problems during the difficult course of the thesis.

\section{References}

[1] Vandermeersch, L., et al.. 新漢文化圈, 南昌: 江西人民出版社. 1993.

[2] Warde, B. The crystal goblet, Sylvan Press. 1955.

[3] 白川靜. 漢字百話, 中央公論社. 1978.

[4] 付小平. "中國漢字藝術發展概況簡評." 美術大觀(12): 71-71. 2011.

[5] 蔣勳. 漢字書法之美: 舞動行草, 遠流出版. 2009.

[6] 柯誌傑 and 蘇煒翔. 字型散步: 日常生活的中文字型學, 臉譜出版. 2014.

[7] 孔新苗 and 張萍. 中西美術比較, 山東畫報出版社. 2002.

[8] 李梵. 漢字的故事, 中國檔案出版社. 2001.

[9]＼cjkstart李廣武. "基於意象觀的漢字藝術視覺表現解讀." 設計(07). 2015.

[10] 梁祖萍. "《文心雕龍·練字》之闡釋." 名作欣賞(09). 2007.

[11] 廖潔連. 喜九四九年後中國字體設計人: 壹字壹生, MCCM Creations. 1996.

[12] 秦楠. "談談漢字的美學價值." 漢字文化(01). 2001.

[13] 施百俊. 美學經濟密碼, 商周出版. 2009.

[14] 徐啟賢、林榮泰 (2011). "漢字的文化創意產業應用探討."

[15] 姚洤銘 and 藏克和. 漢字與書法文化, 廣西敎育出版社. 1996

[16] 藏克和. 漢字取象論, 聖環圖書有限公司. 1995 